\title{
Phenetic Characterization of Nitrogen Fixing Azotobacter from Rhizospheric Soil of Southern Rajasthan
}

\author{
Devendra Jain $^{1 *}$ (D), Gunnjeet Kaur ${ }^{1,2}$, Ali Asger Bhojiya ${ }^{1,3}$ (D), Surya Chauhan ${ }^{1}$, \\ S.K. Khandelwal' ${ }^{1}$, R.H. Meena ${ }^{4}$, Deepak Rajpurohit ${ }^{1}$ and Santosh Ranjan \\ Mohanty ${ }^{5}$ (D) \\ ${ }^{1}$ Department of Molecular Biology and Biotechnology, Rajasthan College of Agriculture, \\ Maharana Pratap University of Agriculture and Technology, Udaipur - 313 001, Rajasthan, India. \\ ${ }^{2}$ School of Agricultural Sciences, Dr. K. N. Modi University, Newai, Tonk - 304 021, Rajasthan, India. \\ ${ }^{3}$ Department of Agriculture and Veterinary Sciences, Mewar University, Chittaurgarh - 312 901, Rajasthan, \\ India. \\ ${ }^{4}$ Department of Soil Science and Agricultural Chemistry, Rajasthan College of Agriculture, MPUAT, \\ Udaipur 313 001, Rajasthan, India. \\ ${ }^{5}$ Indian Institute of Soil Science, Indian Council of Agricultural Research, Bhopal - 462 038, Madhya Pradesh, \\ India.
}

\begin{abstract}
The present research was conducted to characterize the indigenous plant growth promoting (PGP) Azotobacter strains isolated from plant root interface of semi-arid regions of Rajasthan (India) and to study their potential to be used as bio-fertilizers. A total of $\mathbf{1 7 2}$ Azotobacter strains were isolated, purified and based on the morphological test i.e. gram staining, pigmentation, cyst formation, fluorescence etc, broadly classified as Azotobacter. Further the secluded strains were examined for biochemical analysis and plant growth promoting characters. All the isolates showed different biochemical characteristics and significant PGP traits. IAA activity of the Azotobacter strains ranges

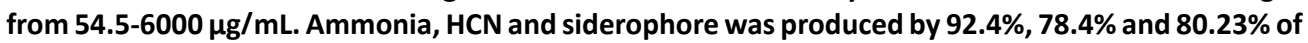
the total isolates respectively. Solubilization of phosphate was observed in $97.6 \%$ of the total isolates. These strains were also characterized for qualitative and quantitative $\mathrm{N}_{2}$ fixation abilities and the result indicated that 114 strains showed positive results on nitrogen free malate agar medium (NFMM) containing bromothymol blue (BTB) and able to produce 18.93-475.6 N-moles $\mathrm{C}_{2} \mathrm{H}_{4} \mathrm{mg}_{\text {protein }} \mathrm{m} \mathrm{h}^{-1}$ of acetylene reduced by Azotobacter strains. In vitro pot studies revealed that the selected native Azotobacter strains having high ARA results significantly increase the plant growth characters. Shoot length, root length, root number and chlorophyll content and leaf number increases by $45.62 \%, 17.60 \%$, $\mathbf{9 7 . 4 9} \%, \mathbf{4 9 . 6 9 \%}$ and $\mathbf{2 7 . 8 3} \%$ respectively in pot inoculated with AZO23-3 as compared to control. These effective strains can further be utilized for development of effective microbial formulations.
\end{abstract}

Keywords:- Biochemical Test, Cyst, Pigmentation, Antibiotic sensitivity, Acetylene Reductase Assay, Pot study

*Correspondence: devroshan@gmail.com; +91 9929840357

(Received: September 29, 2020; accepted: December 16, 2020)

Citation: Jain D, Kaur G, Bhojiya AA, et al. Phenetic Characterization of Nitrogen Fixing Azotobacter from Rhizospheric Soil of Southern Rajasthan. J Pure Appl Microbiol. 2021;15(1): 428-436. doi:10.22207/JPAM.15.1.40

(c) The Author(s) 2021. Open Access. This article is distributed under the terms of the Creative Commons Attribution 4.0 International License which permits unrestricted use, sharing, distribution, and reproduction in any medium, provided you give appropriate credit to the original author(s) and the source, provide a link to the Creative Commons license, and indicate if changes were made. 


\section{INTRODUCTION}

Excessive use of inorganic chemical-based fertilizers is not only cost intensive but also creates the problem of soil, agriculture and environmental management strategies. Organic farming is the most important component for improving plant, soil health and to overcome the uses of chemical fertilizers ${ }^{1}$. To search an alternative approach to usage of chemical fertilizers, the use of biofertilizer is gaining momentum in agriculture. Biofertilizers are organic fertilizers, which are composed of beneficial living microbial inoculants. These microorganisms promotes growth of plants and the healthy structure of soils by converting nutritionally nitrogen, phosphorus, potassium and many essential elements from unavailable to available form for plants ${ }^{2}$. Bio-inoculates also entail organic fertilizers and low input agricultural tool which manifest in an available form due to the symbiosis of micro-organisms and their association with plants ${ }^{3}$.

One of important bio-inoculants is Azotobacter which is gram negative, aerobic and free-living $\mathrm{N}_{2}$-fixing bacteria non-symbiotically fixes the atmospheric nitrogen, degrades cellulose, phosphates and most importantly it degrades lignin in trace amounts ${ }^{4,5}$. It is oval or spherical in shape and capable for forming thick-walled cysts under favorable condition ${ }^{6}$. Azotobacter strains binds with the beyond reach atmospheric nitrogen and liberate it in the form of ammonium ions which is utilized by plants to fix in the soil with an average of $20 \mathrm{~kg} \mathrm{~N} /$ ha per year. Moreover, Azotobacter is also able to multiply at 4.8-8.5 $\mathrm{pH}$ range and fixes atmospheric $\mathrm{N}_{2}$ and the optimum $\mathrm{pH}$ range is 7.0-7.5 . The other $^{2}$ beneficial effects of Azotobacter is that it helps in increasing the overall nitrogenase activity of soil and also posses keratinolytic activity ${ }^{8,9}$. The genus Azotobacter is an adjunct to Pseudomonadaceae family which is a subclass of $\gamma$-Proteobacteria. This subclass is comprehend of seven species: Azotobacter vinelandii, A. chroococcum, A. salinestris, A. nigricans, A. beijerinckii, A. paspali, and A.armeniacus ${ }^{10}$. Azotobacter survives in soil for longer duration due to the formation of cyst. Azotobacter also stimulates plant growth by facilitating the plants to uptake essential nutrients from the surrounding and they also produces phytohormones like auxins, gibberellins, cytokinins ${ }^{11}$. Therefore considering the above properties, Azotobacter sp. is used as a beneficial biological agent, extensively seek for a various crops like wheat, rice, sorghum, sugarcane, maize, sorghum, and maize ${ }^{12}$. To develop commercial biofertilizer the initial steps are isolation and characterization of native Azotobacter strains. Consequently, this study was designed to isolate and characterize Azotobacter for their various plant growth promoting characteristics and $\mathrm{N}_{2}$ fixing attributes.

\section{MATERIAL AND METHODS Isolation of Azotobacter sp}

The Azotobacter sp. was isolated on Nitrogen free Jensen's medium by serial dilution and spread plate technique ${ }^{13}$. The serial soil dilution of soil samples were done upto $10^{-6}$ and afterwards spread on Jenson medium plates. The inoculated petriplates were kept in invert position for incubation at $28 \pm 2^{\circ} \mathrm{C}$ for about 48 h. The Azotobacter colonies were large, ovoid, pleomorphic in shape and were purified on Azotobacter medium ${ }^{14}$ and preserved in glycerol stocks.

\section{Biochemical analysis of Azotobacter sp}

Pure strains of Azotobacter sp. were isolated from soil samples and were characterized according to procedure mentioned in Bergey's Manual of Systematic Bacteriology $y^{15}$. The cyst formation was induced according to the procedure of Socolofsky and Wyss ${ }^{16}$ and the staining of cysts were done by the method of Vela and Wyss ${ }^{17}$. Under biochemical characteristics, starch hydrolysis, $\mathrm{H}_{2} \mathrm{~S}$ production, TSI test, Nitrate reduction, Urease, Catalase and Oxidase reaction were studied. Carbon source i.e., glucose, mannitol, lactose and sucrose utilization were also assayed. Antibiotic sensitivity of Azotobacter isolates were determined by disk agar diffusion method ${ }^{18}$ using standard concentration of antibiotic discs of Ampicillin, Rifampicin, Kanamycin, Chloramphenicol and Penicillin.

\section{PGP activitiesIAA Production}

Quantification measurement of IAA production was followed by the method as described by Gordon and Weber ${ }^{19}$. The produced IAA concentration in the culture was measured by plotting the standard graph of IAA obtained in the range of $10-100 \mu \mathrm{g} / \mathrm{ml}$. 


\section{$\mathrm{NH}_{3}$ Production}

Ammonia production was tested for Azotobacter strains as described by Cappuccino and Sherman ${ }^{20}$. Overnight grown bacterial culture was inoculated in $10 \mathrm{ml}$ peptone broth and incubated at $35 \pm 0.1^{\circ} \mathrm{C}$ for $48 \mathrm{~h}$ in shaking postion. $0.5 \mathrm{~mL}$ of Nessler's reagent was added after incubation.

\section{HCN Production}

Azotobacter culture was streaked on nutrient agar medium, which containedglycine (4.4g per liter) and in the same petriplate a $0.5 \%$ picric acid solution (in $2 \%$ sodium carbonate) soaked Whatman filter paper was placed inside the lid. These plates were sealed with parafilm and incubated at $25 \pm 2^{\circ} \mathrm{C}$ for 4 days and the color change of filter paper was observed (Castric, 1977) $)^{21}$.

\section{Siderophore Production}

Siderophore production was assayed on the Chrome azurol $\mathrm{S}$ agar medium as described by Schwyn and Neilands ${ }^{22}$.

Phosphate solubilizing activity

The potential to solubilize insoluble phosphates on the modified Sperber's medium was determined by measuring clear zone around the colonies ${ }^{23}$.

\section{Estimation of Nitrogen production and fixation Qualitative estimation}

For qualitative estimation of nitrogen production Nitrogen free Malate media, containing with bromothymol blue (BTB) as an indicator, was used for detection of nitrogen fixing activity. Plates were inoculated with purified isolates and incubated at $37^{\circ} \mathrm{C}$ up to $24 \mathrm{~h}$. Those isolates producing blue colored zone on Nitrogen free Malate media were considered nitrogen fixers and they were further tested by quantification of nitrogen fixation by Kjeldahl and acetylene reduction activity (ARA) method.

\section{Nitrogen Production}

Total nitrogen fixation by the Azotobacter isolates in the growing medium was quantified by the method ${ }^{24}$.

Total Nitrogen was calculated and expressed as \% (percentage) using the formula:

\section{Quantitative estimation by ARA}

Quantification of nitrogen fixation was carried out by ARA assay following the method of Stewart et al. ${ }^{25}$ Briefly, five $\mathrm{ml}$ of modified Ashby's medium ${ }^{26}$ were inoculated with Azotobacter and incubated at $30^{\circ} \mathrm{C}$ for $24 \mathrm{~h}$. Further, the cotton plugs of the tubes were replaced with rubber stopper and $5 \mathrm{ml}$ head space was injected with $10 \%(\mathrm{v} / \mathrm{v})$ acetylene and incubated at $30^{\circ} \mathrm{C}$ for $2 \mathrm{~h}$. The $\mathrm{C}_{2} \mathrm{H}_{4}$ production was measured using gas chromatography and the ARA values were recorded as $\mathrm{N}$ moles $\mathrm{C}_{2} \mathrm{H}_{4}$ mg protein ${ }^{-1} \mathrm{~h}^{-1}$.

In vitro studies on the effect of selected Azotobacter on growth of maize seedling

The pot experiment with selected Azotobacter strains having high nitrogenase activities were conducted in plastic pots filled with sterile perlite/vermiculite/coco-peat mixture in triplicate as per CRD design on maize (FEM-2 variety $)^{27}$. Various plant growth parameters like leaf number, chlorophyll content of leaf, average shoot length, root length and root numbers, were analyzed.

\section{RESULT AND DISCUSSION}

Isolation and characterization of the Azotobacter strains

Total of 172 Azotobacter strains were isolated from different rhizospheric soil samples on Azotobacter selected media. The phenetic characteristics of Azotobacter strains are summarized (supplementary sheet Table 1). Most of the bacterial colonies isolated were circular (even) in shape, whitish in colour and the size ranges between 1.0-4.0 mm in size Jimenez et al. ${ }^{28}$, reported that most Azotobacter isolates showed circular form, entire margin with whitish (cream color), smooth, irregular, shining, 3-8mm diameter colonies. All the bacterial isolates were gram negative. Out of 172 isolates, 22 produced water soluble yellow pigment, 10 produced brown pigment, 2 isolates produced red pigment. Out of 172 isolates, 27 showed a green fluorescence, 3 presented a yellow fluorescence and 5 displayed a red fluorescence. Only two isolates did not form cyst, remaining 170 isolates formed cyst. Shaikh and Mohd. Shakir ${ }^{29}$ performed cyst formation test on 39 Azotobacter vinelandii, and found that 38 out of 39 Azotobacter produced cyst.

All the bacterial isolates were characterized by detecting their biochemical characteristics. Results of the investigation results indicated that out of 172 isolates, 129 isolates were found to hydrolyze starch; 146 isolates were 
Jain et al. | J Pure Appl Microbiol | 15(1):428-436 | March 2021 | https://doi.org/10.22207/JPAM.15.1.40

\begin{tabular}{|c|c|c|c|c|c|c|c|}
\hline \multirow{2}{*}{\multicolumn{4}{|c|}{$\begin{array}{l}\text { Table 1. Qualitative and quantitative estimation of } \\
\text { nitrogen fixation by Azotobacter strains }\end{array}$}} & \multirow{3}{*}{$\begin{array}{l}49 . \\
50 . \\
51 . \\
52 .\end{array}$} & \multirow{3}{*}{$\begin{array}{l}\text { AZO30-1 } \\
\text { AZO30-2 } \\
\text { AZO31-1 } \\
\text { AZO32-1 }\end{array}$} & \multirow{3}{*}{$\begin{array}{c}98.2 \\
178 \\
191.2 \\
102.4\end{array}$} & \multirow{3}{*}{$\begin{array}{c}55.34392 \\
164.328 \\
23.86243 \\
39.89418\end{array}$} \\
\hline & & & & & & & \\
\hline \multirow{4}{*}{ S.No. } & \multirow{4}{*}{ Isolates } & \multirow{4}{*}{$\begin{array}{l}\mathrm{N}_{2} \text { Fixed } \\
\text { (PPM) }\end{array}$} & Nmoles & & & & \\
\hline & & & \multirow{3}{*}{$\begin{array}{c}\text { Nmoles } \\
\mathrm{C}_{2} \mathrm{H}_{4} \mathrm{mg} \\
\text { protein }^{-1} \mathrm{hr}^{-1}\end{array}$} & 53. & AZO33-1 & 100 & 158.3175 \\
\hline & & & & 54. & AZO34-2 & 198 & 60.07407 \\
\hline & & & & 55. & AZO35-1 & 77.22 & 51.59788 \\
\hline 1. & AZO1-1 & 48.95 & 59.30159 & 56. & AZO35-2 & 121.1 & 62.69841 \\
\hline 2. & AZO1-2 & 48.95 & 87.79894 & 57. & AZO36-2 & 150.1 & 41.01587 \\
\hline 3. & AZO1-4 & 80.68 & 62.86772 & 58. & AZO37-1 & 139.2 & 59.64021 \\
\hline 4. & AZO2-2 & 35.36 & 56.95238 & 59. & AZO38-1 & 67 & 58.68783 \\
\hline 5. & AZO2-3 & 123.73 & 57.48148 & 60. & AZO39-1 & 89.2 & 92.07407 \\
\hline 6. & AZO2-11 & 42.16 & 49.24868 & 61. & AZO39-2 & 56.89 & 37.10053 \\
\hline 7. & AZO2-12 & 395.65 & 433.0931 & 62. & AZO40-1 & 56.22 & 88.49735 \\
\hline 8. & AZO2-13 & 42.16 & 34.08466 & 63. & AZO40-2 & 120 & 132.4021 \\
\hline 9. & AZO2-15 & 42.16 & 201.3968 & 64. & AZO41-1 & 122.4 & 72.79365 \\
\hline 10. & AZO3-6 & 60.28 & 27.30159 & 65. & AZ041-2 & 78.05 & 80.57143 \\
\hline 11. & AZO3-7 & 80.68 & 59.66138 & 66. & AZO42-1 & 67 & 175.3228 \\
\hline 12. & AZO4-5 & 55.75 & 50.74074 & 67. & AZO43-1 & 89.22 & 46 \\
\hline 13. & AZO4-7 & 28.56 & 84.87831 & 68. & AZO44-1 & 108 & 48.07407 \\
\hline 14. & AZO4-11 & 17.23 & 125.1534 & 69. & AZO45-1 & 78 & 38.66667 \\
\hline 15. & AZO5-2 & 67.08 & 22.46561 & 70. & AZO45-2 & 178 & 43.51323 \\
\hline 16. & AZO6-1 & 37.62 & 30.7619 & 71. & AZO46-1 & 152.1 & 34.19048 \\
\hline 17. & AZO6-2 & 89.74 & 43.82011 & 72. & AZO46-2 & 98.2 & 65.15344 \\
\hline 18. & AZO6-3 & 64.82 & 76.8254 & 73. & AZO47-1 & 111.1 & 128.0476 \\
\hline 19. & AZO7-1 & 53.49 & 41.60847 & 74. & AZO47-2 & 156 & 74.26455 \\
\hline 20. & AZO8.2 & 64.82 & 399.7778 & 75. & AZO48-1 & 89 & 58.71958 \\
\hline 21. & AZ010-1 & 85.21 & 36.10582 & 76. & AZO49-2 & 102.3 & 98.67725 \\
\hline 22. & AZO11-1 & 48.95 & 22.67725 & 77. & AZO51-1 & 101 & 24.56085 \\
\hline 23. & AZO11-2 & 37.62 & 55.49206 & 78. & AZO52-1 & 39.89 & 93.74603 \\
\hline 24. & AZO12-2 & 58.02 & 22.35979 & 79. & AZO52-4 & 103.34 & 123.164 \\
\hline 25. & AZO13-1 & 53.49 & 62.16931 & 80. & AZ052-5 & 62.55 & 36.31746 \\
\hline 26. & AZO13-2 & 60.28 & 29.8836 & 81. & AZO52-6 & 58.02 & 93.56614 \\
\hline 27. & AZO14-1 & 151.22 & 53.33333 & 82. & AZO56-1 & 189 & 53.14286 \\
\hline 28. & AZO17-1 & 112.4 & 51.78836 & 83. & AZ056-2 & 152 & 45.95767 \\
\hline 29. & AZO17-4 & 53.49 & 53.67196 & 84. & AZO4.3 & 70 & 191.7778 \\
\hline 30. & AZO17-7 & 64.82 & 55.24868 & 85. & AZO4.6 & 63 & 35.28042 \\
\hline 31. & AZO17-8 & 80.68 & 78.13757 & 86. & AZO5.4 & 79 & 116.0317 \\
\hline 32. & AZO17-10 & 67.08 & 56.78307 & 87. & AZO6.4 & 57 & 42.6455 \\
\hline 33. & AZO17-11 & 78.41 & 133.1217 & 88. & AZO8.3 & 71 & 178.6349 \\
\hline 34. & AZO17-12 & 139.59 & 41.01587 & 89. & AZO8.4 & 48 & 145.3122 \\
\hline 35. & AZO19-1 & 80.68 & 124.6243 & 90. & AZO11.5 & 53 & 61.19577 \\
\hline 36. & AZO19-2 & 44.42 & 43.60847 & 91. & AZO19.4 & 49 & 33.33333 \\
\hline 37. & AZO20-1 & 123.73 & 290.0106 & 92. & AZO52.7 & 64 & 53.68254 \\
\hline 38. & AZO20-2 & 46.69 & 372.836 & 93. & AZO52.8 & 80 & 70.44444 \\
\hline 39. & AZO20-3 & 46.69 & 107.9577 & 94. & AZO52.9 & 66 & 21.01587 \\
\hline 40. & AZO21-1 & 105.6 & 121.8201 & 95. & AZO52.10 & 36 & 72.77249 \\
\hline 41. & AZO22-1 & 39.89 & 304.6772 & 96. & AZO DP-5 & 55 & 18.93122 \\
\hline 42. & AZO23-2 & 193.98 & 86.61376 & 97. & AZO DP-6 & 99 & 69.12169 \\
\hline 43. & AZO23-3 & 35.36 & 475.6402 & 98. & AZOS-4 & 70 & 148.0106 \\
\hline 44. & AZO23-6 & 114.67 & 48.2963 & 99. & AZOS-5 & 85 & 29.50265 \\
\hline 45. & AZO23-7 & 51.22 & 39.84127 & 100. & AZO AV & 69 & 42.19048 \\
\hline 46. & AZO25-1 & 68 & 54.93122 & 101. & AZO5 M & 78 & 106.3386 \\
\hline 47. & AZO25-1 & 56.4 & 54.93122 & 102. & AZO5 Al & 83 & 95.66138 \\
\hline 48. & AZO26-1 & 79.32 & 80.06349 & 103. & AZO5AII & 61 & 29.25926 \\
\hline
\end{tabular}

Journal of Pure and Applied Microbiology 


$\begin{array}{lccc}\text { 104. } & \text { AZO6PG1 } & 51 & 111.873 \\ \text { 105. } & \text { AZO15M } & 89 & 41.93651 \\ \text { 106. } & \text { AZO7AII } & 75 & 77.38624 \\ \text { 107. } & \text { AZO4 A } & 68 & 24.56085 \\ \text { 108. } & \text { AZO12A } & 80 & 55.64021 \\ \text { 109. } & \text { AZO6A1 } & 78 & 337.7037 \\ \text { 110. } & \text { AZO6AII } & 77 & 50.2963 \\ \text { 111. } & \text { AZO7M } & 44 & 33.62963 \\ \text { 112. } & \text { AZOMAAM } & 55 & 89.54497 \\ 113 . & \text { AZO15AI } & 49 & 107.3968 \\ 114 . & \text { AZO2W } & 95 & 50.58201\end{array}$

found to produce $\mathrm{H}_{2} \mathrm{~S} ; 163$ isolates hydrolyze urea; 151 isolates gave positive reaction for oxidase test; 153 isolates reduces nitrate and 117 isolates gave positive reaction for TSI test. All the isolates gave positive reaction for catalase activity. The results of biochemical properties of Azotobacter species observed by Tejera et al. ${ }^{30}$ were in close agreement with the results observed in the present study. These findings clearly indicated the distribution of Azotobacter species in different soil ecosystem. Ahmad et al. ${ }^{31}$ studied the biochemical tests in Azotobacter species and reported that Azotobacter are positive for Catalase, and Starch hydrolysis. Similarly, Shrivastava ${ }^{32}$ also reported all the isolates were positive for catalase. Most of the Azotobacter isolates utilize sucrose, lactose, mannitol and glucose as carbon source used in the present study. Out of 172 isolates, 18 isolates utilize 4 sugars; 13 isolates utilize 3 sugars; 42 isolates utilize 2 sugars and 78 isolates utilize 1 sugar as carbon source.

For antibiotic resistance, 172 isolates of Azotobacter strains were tested by the antibiotic disk method on Jenson medium plates. Table 2 in supplementary table sheet shows the resistance pattern of 172 Azotobacter isolates against Ampicillin, Rifampicin, Kanamycin, Chloramphenicol and Penicillin antibiotics discs. Multiple antibiotic resistances were seen in a majority of the isolates. Out of 172 strain 105 isolates showed sensitivity and 87 shows resistance against Ampicillin. Only 3 strains showed resistance and 169 were sensitive for Rifampicin. 122 isolates were sensitive and 50 are resistant for Kanamycin. Only one strain out of 172 shows resistance for Chloramphenicol. 85 Azotobacter strains were found resistant to penicillin while 87 were sensitive to penicillin. Bhaduri et al. ${ }^{32}$ studied among 18 isolates of Asymbiotic $\mathrm{N}_{2}$ fixers (Azotobacter) and symbiotic $\mathrm{N}_{2}$-fixers (Rhizobium spp for the antibiotic resistance and susceptibility of against different antibiotics including Chloramphenicol and Rifampicin. The antibiotics ampicillin, chloramphenicol, kanamycin, penicillin and rifampicin resistance tested on 117 isolates of $A$. chroococcum were tested by the antibiotic disc method by Sindhu et al. ${ }^{33}$.

\section{Plant growth promoting (PGP) activities}

Pink color appearance in bacterial culture after addition of orthophosphoric acid and Salkowski reagent to supernatant in LB broth confirmed that bacterial strains are positive for IAA production. In the present study IAA activity ranges from $54.5-6000 \mu \mathrm{g} / \mathrm{mL}$. Maximum IAA production $6000 \mu \mathrm{g} / \mathrm{ml}$ was observed for isolate AZO 17-6 followed by $1500 \mu \mathrm{g} / \mathrm{mL}$ for isolates AZO1-1, AZO13, AZO2-8, AZO4-11, AZO17-2, AZO17-3, AZO17-4, AZO22-2 and AZO22-4. Minimum IAA production $54.5 \mu \mathrm{g} / \mathrm{mL}$ was observed for isolate AZO 53-1. Ahmad et al. ${ }^{35}$ reported that Azotobacter spp. produced $38.82 \mu \mathrm{g} / \mathrm{mL}$ IAA in culture medium supplemented with Tryptophan at the rate of $5 \mathrm{mg} /$

Table 2. In vitro studies on the effect of Azotobacter strains on growth and yield of maize seedling

\begin{tabular}{lcccccc}
\hline S.No. & Treatment & $\begin{array}{c}\text { Average Shoot } \\
\text { Length }(\mathrm{cm})\end{array}$ & $\begin{array}{c}\text { Average Root } \\
\text { Length }(\mathrm{cm})\end{array}$ & $\begin{array}{c}\text { Average Root } \\
\text { Number }\end{array}$ & $\begin{array}{c}\text { Average Leaf } \\
\text { number }\end{array}$ & $\begin{array}{c}\text { Total Chlorophyll } \\
(\mu \mathrm{g} / \mathrm{ml})\end{array}$ \\
\hline 1 & Control & $13.7 \pm 0.12$ & $34.6 \pm 0.66$ & $9.96 \pm 0.58$ & $6 \pm 1.0$ & $35.74 \pm 0.95$ \\
2 & AZO2-12 & $18.75 \pm 0.20$ & $39.7 \pm 0.95$ & $18.93 \pm 1.15$ & $6.67 \pm 0.58$ & $51.57 \pm 1.90$ \\
3 & AZO8.2 & $17.12 \pm 0.50$ & $37.37 \pm 0.96$ & $13.67 \pm 0.58$ & $6.67 \pm 1.53$ & $46.76 \pm 1.49$ \\
4 & AZO22-1 & $15.59 \pm 0.38$ & $36.75 \pm 1.05$ & $14.67 \pm 0.58$ & $6.0 \pm 0.0$ & $39.91 \pm 1.20$ \\
5 & AZO23-3 & $19.95 \pm 0.51$ & $40.69 \pm 1.03$ & $19.67 \pm 0.58$ & $7.67 \pm 0.58$ & $53.50 \pm 1.15$ \\
6 & AZO6A1 & $16.56 \pm 0.52$ & $37.12 \pm 0.98$ & $15.33 \pm 1.53$ & $6.0 \pm 0.58$ & $45.72 \pm 1.27$ \\
\hline
\end{tabular}

Value \pm SD; Data are recorded after 30 days of germination 
$\mathrm{mL}$. Kannapiran and Ramkumar ${ }^{36}$ have reported that the amount of IAA produced by Azotobacter chroococcum and Azotobacter beijerinckii were 23.6 and $17.6 \mu \mathrm{g} / \mathrm{mL}$ respectively. Deshmukh and Vidhale ${ }^{37}$ isolated four Azotobacter species from the rhizospheric soil in the alluvial valley of Purna river and its tributaries occupy parts of Amravati and found to produce high level (9.2 to $40.0 \mathrm{mg}$ / $\mathrm{mL}$ ) of IAA. According to Mali and Bodhankar ${ }^{38}, 25$ isolates of Azotobacter chroococcum isolated from the rhizosphere soil of groundnut were tested for production of IAA in $55 \mu \mathrm{g} / \mathrm{mL}$.

The production of ammonia is an essential PGPR trait that can influence the plants growth indirectly. Estimation of ammonia production examined by the development of faint yellow to dark brown color after addition of Nessler's reagent to overnight grown bacterial culture in peptone broth indicated $92.4 \%$ ammonia production by the bacterial isolates the. These results are similar to those of Ahmad et al. ${ }^{39}$, who revealed the production of ammonia commonly detected in the Azotobacter isolates. HCN production was indicated by the change in yellow to brown to red color of the filter paper strips. Out of 172 isolates, $78.4 \%$ isolates gave positive reaction for $\mathrm{HCN}$ production. For siderophore production, formation of yellow orange halo around the colony on CAS agar medium showed that $80.2 \%$ of 172 isolate produce siderophore. Altaf and Malik ${ }^{40}$ examined the 15 Azotobacter sp. for various PGPR activity and found that $33 \%$ and $80 \%$ of the isolates showed $\mathrm{HCN}$ and siderophore production respectively. Solubilization of phosphorous was indicated by observing for the zone of clearance around the bacterial colony in the plates. Out of 172 isolates, $97.6 \%$ isolates solubilize phosphate producing clear zone around the colony. The results observed were in close agreement with the previous works of Farajzadeh et al. ${ }^{41}$.

\section{Estimation of Nitrogen production and fixation}

Azotobacter strains were preliminary screened for nitrogen fixation on nitrogen free Malate agar medium containing Bromothymol Blue (BTB) as an indicator. Out of 172 bacterial isolates, 114 isolates produced blue color zone on medium indicating fixation of nitrogen by them. Further, these 114 Azotobacter isolates were quantified for nitrogen production by Kjeldahl method. Nitrogen production ranges from 17.23395.6 ppm. Maximum nitrogen production 395.6 ppm was observed for isolate AZO2-12 followed by 198 ppm for isolate AZO34-2. Minimum nitrogen production $17.23 \mathrm{ppm}$ was observed for isolate AZO4-11.

All the 114 Azotobacter isolates were screened for acetylene reduction ability (ARA). The comparison of nitrogenase activity of all efficient nitrogen-fixing isolates is shown in Table 1 . All the isolates showed nitrogenase activity ranging from 18.93-475.6 Nmoles $\mathrm{C}_{2} \mathrm{H}_{4}$ mg protein ${ }^{-1} \mathrm{hr}^{-1}$. Maximum nitrogenase activity was observed for isolate AZO23-3 i.e 475.64 Nmoles $\mathrm{C}_{2} \mathrm{H}_{4} \mathrm{mg}$ protein $^{-1} \mathrm{~h}^{-1}$ and of AZO DP-5 was observed to be the least i.e. 18.93 Nmoles $\mathrm{C}_{2} \mathrm{H}_{4}$ mg protein ${ }^{-1} \mathrm{~h}^{-1}$. In present study the obtained ARA ranges were significantly higher than other observations and corroborated with Rodelas et al. ${ }^{42}$ who reported the ARA results of pure cultures of strains were between 9.70 to $257.73 \mathrm{nmol}_{2} \mathrm{H}_{4} \mathrm{~h}^{-1}$ vial $^{-1}$. According to Tejera et al. ${ }^{28} A$. chroococcum isolates from soil showed ARA production within ranged between 79.6 to $329.5 \mathrm{nmol} \mathrm{C}_{2} \mathrm{H}_{4} \mathrm{~h}^{-1}$ culture.

Nitrogen fixation potentiality of the selected isolates of Azotobacter sp was estimated by Akhter et al. ${ }^{43}$, ranging from 04.95 to 10.55 mg N/g substrate. Kizilkya ${ }^{44}$ reported that the Azotobacter fix nitrogen in the range of 3.50 to $29.35 \mu \mathrm{g} \mathrm{N} \mathrm{mL}{ }^{-1}$ for medium culture. Variation in efficiency of Azotobacter may be due to difference in strains and different growth conditions being used in different studies ${ }^{45}$.

Studies of In vitro effect of Azotobacter on growth and yield of maize seedling

The experiment of pot culture was conducted in plastic pots filled with sterile planting mixture. Plant growth promoting activity of Azotobacter isolates were studied on FEM-2 variety of Maize. Cultivable seeds were treated with Azotobacter inoculant thorough seed bacterization method and sown. Five Azotobacter strains with higher ARA values were selected for pot studies. Pot experiment data were recorded after 30 days of germination were summarized in Table 2.

O Maize seedlings raised from bacterized seeds with selected Azotobacter isolates, observed higher growth in treated ones as compared with absolute control. This indicates the positive effect 
of Azotobacter strains on maize plantlet. Leaf number, total chlorophyll content, Shoot length, root number, root length, have been significantly increased in the maize plantlet inoculated with the selected Azotobacter strains as compared to uninoculated control.

Shoot length, root length, root number and chlorophyll content increases by $45.62 \%$, $17.60 \%, 97.49 \%$ and $49.69 \%$ respectively in pot inoculated with AZO23-3 followed by AZO212 (36.86\%, $14.74 \%, 90.06 \%$ and $44.29 \%$, respectively). Leaf number increases by $27.83 \%$ in pot inoculated with AZO23-3 followed by AZO212 and AZO8.2 (11.17\%). All the Azotobacter strains significantly influenced the observed parameters as compared to uninoculated control and contributed to plant growth. Similar finding was observed by Mahato and Neupane ${ }^{46}$ who reported Azotobacter seed bacterization in maize promote the growth of treated plants and find increased growth in root and shoot lengths. Perdomo et al. ${ }^{47}$ reported Azotobacter bacterial inoculation in cotton positively influenced plant growth parameters and reduced $50 \%$ nitrogen fertilization doses. These findings advocated the application of Azotobacter for improvement of plant growth due to their intrinsic abilities of fixing atmospheric nitrogen and expressing plant growth-promoting substances.

The plant growth promoting traits and the nitrogen fixation by the local Azotobacter strains is a very critical for the selection of such strains for biofertilizer formulations in order to replace the ineffective strains. The results indicated that inoculation by multi PGP Azotobacter strains significantly improved the plant growth under in vitro condition and may be used for commercial production. Hence, the dedicated field studies are required to confirm the efficacy of these Azotobacter strains.

\section{SUPPLEMENTARY INFORMATION \\ Supplementary information accompanies this article at https://doi.org/10.22207/JPAM.15.1.40 \\ Additional file: Additional Table S1- S2.}

\section{ACKNOWLEDGMENTS}

The financial assistance from All India Network Project on soil biodiversity and biofertilizers and Rastriya Krishi Vikas Yojana (RKVY) research project are highly acknowledged. The support of Dean, RCA and Director of Research, MPUAT is also acknowledged.

\section{CONFLICT OF INTEREST}

The authors declare that there is no conflict of interest.

\section{AUTHORS' CONTRIBUTION}

DJ conceived and designed the experiments; GK, AAB, SC performed laboratory experiments; DJ, SKK, RHM and DR wrote the manuscript. All authors read and approved the final manuscript.

\section{FUNDING}

This study was supported by the AINPSBB grant (10-t-37) from ICAR, New Delhi and RKVY grants (10-CSA-65A-V) from Government of Rajasthan.

\section{DATA AVAILABILITY}

All datasets generated or analyzed during this study are included in the manuscript and also in the Supplementary Files.

\section{ETHICS STATEMENT}

This article does not contain any studies with human participants or animals performed by any of the authors.

\section{REFERENCES}

1. Govindan K, Thirumurugan V. Synergistic association of Rhizobium with phosphate solubilizing bacteria under different sources of nutrient supply on productivity and soil fertility in soybean (Glycine max). Indian J Agron. 2005; 50: 214-217.

2. Rokhzadi A, Asgharzadeh A, Darvish F, Nourmohammadi $G$, Majidi E. Influence of plant growth-promoting rhizobacteria on dry matter accumulation and yield of chickpea (Cicer arietinum L.) under field condition. Am Euras J Agric Environ Sci. 2008;3:253-257.

3. Sujanya S, Chandra S. "Effect of part replacement of chemical fertilizers with organic and bio-organic agents in ground nut, Arachis hypogeal. Journal of Algal Biomass Utilization. 2011;2(4):38-41.

4. Gandora V, Gupta RD, Bhardwaj KKR. Abundance of Azotobacter in great soil groups of North-West Himalayas. J Indian Soc Soil Sci .1998;46(3):379-383. 
5. Salhia B. The Effect of Azotobacter chrococcumas Nitrogen biofertilizer on the growth and yield of Cucumissativus. The Islamic University Gaza, Deanery of Higher Education Faculty of Science, Master of Biological Sciences, Botany. 2013.

6. Narula N, Gupta KG, Ammonia excretion by Azotobacter chroococcum in liquid culture and soil in the presence of manganese and clay minerals. Plant and Soil. 1986;93: 205-209. doi: 10.1007/BF02374222

7. Dilworth MJ, Eady RR, Eldridge ME. The vanadium nitrogenase of Azotobacter chroococcum Reduction of acetylene and ethylene to ethane. Biochem J 1988;249:745-751. doi: 10.1042/bj2490745

8. Mamangkey J, Suryanto D, Munir E, Mustopa AZ. Keratinase Activity of A Newly Keratinolytic Bacteria, Azotobacter chroococcum B4. J Pure Appl Microbiol. 2020;14(2):1203-1211. doi: 10.22207/ JPAM.14.2.15

9. AlMaroai YA. Response of Soil Microorganisms, Nitrogenase Activity and Growth of Onion Plants to the Interaction between Glomus mosseae and Azotobacter chroococcumre.J Pure Appl Microbiol. 2019;13(4):20872095. doi: 10.22207/JPAM.13.4.20

10. Kennedy C, Rudnick P, MacDonald M, Melton T. "Genus III: Azotobacter," in Bergey's Manual of Systematic Bacteriology. TheProteobacteria, Part B, the Gammaproteobacteria, G. M.Garrity, Ed.,Springer, NewYork, NY,USA, $2^{\text {nd }}$ edition. 2005;2:384-402.

11. Joseph B, Patra RR, Lawrence R. Characterization of plant growth promoting rhizobacteria associated with chickpea (Cicer arietinum L). Int J Plant Prod. 2007;1:141-152. doi: 10.22069/IJPP.2012.532

12. Inamdar S, Kantikar RU, Watve MG. Longevity of Azotobacter cysts and a model for optimization of cyst density in liquid bioinoculants. Current Science. 2000;78(6):234-240.

13. Jensen HL. The Azotobacteriaceae. Bacteriology Review. 1954;18:195-214.

14. Whitman WB. Bergey's Manual Of Systematic Bacteriology, in N.R. Krieg, J.T. Staley, D.R. Brown, B.P. Hedlund, B.J. Paster, N.L. Ward, W. Ludwig, W.B. Whitman (Eds.) Springer, USA. 2010;976.

15. Brenner DJ, Krieg NR and Staley JT. Bergy's Manual of Systematic Bacteriology, $2^{\text {nd }}$ Ed.The Proteobacteria part B, The Gammaproteobacteria. Springer Science and Business Media, Inc., New York, USA. 2005. doi: 10.1007/0-387-29298-5

16. Socolofsky MD, Wyss O. Cysts of Azotobacter. J Bacteriol. 1961;81(6):946-954. doi: 10.1128/ JB.81.6.946-954.1961

17. Vela GR, Wyss O. Improved stain for visualization of Azotobacter encystment. J Bacteriol. 1964;87(2):476477. doi: $10.1128 / J B \cdot 87.2 .476-477.1964$

18. Berry AL, Garcia F, Thrupp LD. An improve single disc method for testing the antibiotic susceptibility of rapidly growing pathogens. Am J Clin Patho. 1970;53(2):149-158. doi: 10.1093/ajcp/53.2.149

19. Gordon, Weber RP. Colorimetric estimation of indoleacetic acid. Plant Physiol. 1951;26(1):192-195. doi: 10.1104/pp.26.1.192

20. Cappuccino JC, Sherman N. Microbiology: A Laboratory Manual, $3^{\text {rd }}$ Ed. Benjamin/ cummings Pub. Co., New
York. 1992;125-179

21. Castric PA. Glycine metabolism by Pseudomonas aeruginosa: hydrogen cyanide biosynthesis. J Bacteriol. 1977;130(2):826-831. doi: 10.1128/JB.130.2.826831.1977

22. Schwyn B, Neilands JB. Universal chemical assay for the detection and determination of siderophores. Analytical Biochem. 1987;160(1):47-56. doi: 10.1016/0003-2697(87)90612-9

23. Malboobi MA, Owlia P, Behbahani M, et al. Solubilization of organic and inorganic phosphates by three highly efficient soil bacterial isolates. World J Microbiol Biotechnol. 2009;25:1471-1477. doi: 10.1007/s11274-009-0037-z

24. Kjeldahl JZ. A new method for the determination of nitrogen in organic bodies. Anal Chem. 1983;22:36.

25. Stewart WDP, Fitzgerald GP, Burris RH. In situ studies on N2-fixation using the acetylene reduction technique. Proc Natl Acad Sci. 1967;58(5):2071-2078. doi: 10.1073/pnas.58.5.2071

26. Hegazi NA, Neimela SA. A note on the estimation of Azotobacter densities by membrane filter technique. J Appl Bacteriol. 1976;41(2):311-313. doi: 10.1111/ j.1365-2672.1976.tb00635.x

27. Kour $R$, Jain $D$, Bhojiya AA, et al. Zinc biosorption, biochemical and molecular characterization of plant growth-promoting zinc-tolerant bacteria. 3Biotech. 2019; 9:421. doi: 10.1007/s13205-019-1959-2

28. Jimenez DJ, Montana JS, Martinez MM. Characterization of free nitrogen fixing bacteria of the genus Azotobacter in organic Vegetable-grown colombian soils. Braz J Microbiol. 2011;42:846-858. doi: 10.1590/S151783822011000300003

29. Shaikh Z, Shakir M. Screening, Isolation and Characterization of Azotobacter Vinelandii IN Soils of various fields and Orchards. Research Journal of Life Science, Bioinformatics, Pharmaceutical and Chemical Sciences. 2018;4(3):349-358. doi: 10.26479/2018.0403.31

30. Tejera N, Lluch C, Martinez-Toledo MV, Gonzalez-Lopez J. Isolation and characterization of Azotobacter and Azospirillum strains from the sugarcane rhizosphere. Plant Soil. 2005;270(1):223232. doi: 10.1007/s11104-004-1522-7

31. Ahmad B, Nigar S, Malik NA, et al. Isolation and characterization of cellulolytic nitrogen fixing Azotobacter species from wheat rhizosphere of Khyber Pakhtunkhwa. World App/Sci J. 2013;27(1):51-60. doi: 10.5829/idosi.wasj.2013.27.01.81120

32. Shrivastava UP. Isolation and initial characterization of diazotrophic plant growth promoting rhizobacteria (PGPR) from rice rhizosphere of Parsa and Bara district of Nepal Int J Pharm Life Sci. 2013;4(3) 2481-2488.

33. Bhaduri J, Kundu P, Mitra D, Roy SK. Isolation and characterisation of Nitrogen Fixing Bacteria (Azotobacter Sp.) from Tea field soil of Dooars and Darjeeling region of North Bengal, India. International Journal of Engineering Science Invention.2016;5(8):46-51.

34. Sindhu SS, Grover V, Narula N, Lakshminarayana K. Occurrence of Multiple Antibiotic Resistance 
in Azotobacter chroococcum. Zentralbl Mikrobiol 1989;144(2):97-101. doi: 10.1016/S02324393(89)80071-X

35. Ahmad F, Ahmad I, Khan MS. Indole acetic acid production by the indigenous isolates of Azotobacter and fluorescent Pseudomonas in the presence and absence of tryptophan. Turk J Biol. 2005;29:29-34.

36. Kannapiran E, Ramkumar VS. Inoculation effect of nitrogen-fixing and phosphate-solubilizing bacteria to promote growth of black gram (Phaseolus mungo Roxb; Eng). Annals of Biological Research. 2011;2(5):615621.

37. Deshmukh RR, Vidhale NN. Production of plant growth promoting indole acetic acid by Azotobacter from saline belt of vidarbha region. Indian J Appl Res. 2015;5(5):21.

38. Mali GV, Bodhankar MG. Antifungal and phytohormone potential of Azotobacter chroococcum isolates from ground nut (Arachis hypogeal L.) rhizosphere. Asian J Exp Sci. 2005;23(1):293-297.

39. Ahmad F, Ahmad I, Khan MS. Screening of free-living rhizobacteria for their multiple plant growth promoting activities. Microbiological Research. 2008;163(2):173181. doi: 10.1016/j.micres.2006.04.001

40. Altaf MM, Malik A. Detection of Plant Growth Promoting Activities among Azotobacter sp. Isolated from the Soil Receiving Pulp and Paper Mill Effluents. Acta Scientific Microbiology.2019;2(3):36-45.

41. Farajzadeh D, Yakhchali B, Aliasgharzad N, SokhandanBashir N, Farajzadeh M. Plant Growth Promoting
Characterization of Indigenous Azotobacteria Isolated from Soils in Iran. Curr Microbiol. 2012;64:397-403. doi: 10.1007/s00284-012-0083-x

42. Rodelas B, Gonzalez LJ, Pozo C, Salmeron V, Toledo MMV. Response of faba bean (Vicia faba L.) to combined inoculation with Azotobacter and Rhizobium leguminosarum bv. viceae. App/Soil Ecol. 1999;12(1):5159. doi: 10.1016/S0929-1393(98)00157-7

43. Akhter MS, Hossain SJ, Hossain SA, Datta RK. Isolation and Characterization of Salinity Tolerant Azotobacter sp. Greener Journal of Biological Sciences. 2012;2(3):043051. doi: 10.15580/GJBS.2012.3.110312207

44. Kizilkaya R. Nitrogen fixation capacity of Azotobacter spp. strains isolated from soils in different ecosystems and relationship between them and the microbiological properties of soils. J Environ Biol. 2009;30(1):73-82.

45. Din $M$, Nelofer $R$, Abdullah $M$, et al. Production of nitrogen fixing Azotobacter (SR-4) and phosphorus solubilizing Aspergillus niger and their evaluation on Lagenaria siceraria and Abelmoschus esculentus. Biotechnol Rep (Amst). 2019;22:00323. doi: 10.1016/j. btre.2019.e00323

46. Mahato S, Neupane S. Comparative study of impact of Azotobacter and Trichoderma with other fertilizers on maize growth. Journal of Maize Research and Development. 2017;3(1):1-16. doi: 10.3126/jmrd. v3i1.18915

47. Perdomo FR, Abril J,Camelo M, et al. Azotobacter chroococcum as a potentially useful bacterial biofertilizer for cotton (Gossypium hirsutum): Effect in reducing $\mathrm{N}$ fertilization. Revista Argentina de Microbiologia. 2017;49(4):377-383. doi: 10.1016/j. ram.2017.04.006 